\title{
REQUIREMENT ANALYSIS OF DEVELOPMENT OF INTEGRATED ISLAMIC VALUES LABORATORY WORKSHEETS USING FLIP PDF PROFESSIONAL APPLICATIONS IN GENERAL BIOLOGY COURSES
}

\author{
Meliyani", H. Mukhlis Rohmadi and Ridha Nirmalasari \\ Department of Mathematics and Natural Sciences, Faculty of Tarbiyah and Teacher Training, \\ IAIN Palangka Raya, Indonesia \\ *Email: melispt2017@gmail.com
}

Accepted: January 09, 2022. Approved: January 14, 2022. Published: January 15, 2022

\begin{abstract}
A needs analysis has been carried out for the development of a laboratory worksheet based on Islamic values in general biology courses. Needs analysis was carried out through interviews with general biology lecturers, laboratory work assistants and students. The activity was also followed by a field study. The data analysis technique is qualitative descriptive analysis. The results of the interviews showed that 1 . the laboratory work module used was unattractive and impractical so that it made it difficult for students to understand work procedures, 2) the laboratory work module used had not been integrated with Islamic values so that it was not in accordance with the learning plan made by the lecturer. The results of the needs analysis showed that the lecturers and laboratory work assistants strongly agreed to use general biology laboratory work guidelines integrated with Islamic values using the Flip PDF Professional application. Furthermore, 95.5\% of students stated the need for the development of laboratory work integrated with Islamic values. $54.5 \%$ of students stated that general biology laboratory work is difficult to understand. $72.2 \%$ of students agree that the developed guide is in the form of an e-book and $95.5 \%$ of students want to develop a practical and interesting general biology laboratory work guide.
\end{abstract}

Keywords: Needs Analysis, Laboratory Work Module, Flip PDF Professional, Integration of Islamic Values

\section{INTRODUCTION}

The most important means to develop selfpotential and the quality of human resources is education [1-3]. Law of the Republic of Indonesia No. 20 of 2003, which explains the education system, states that "National Education functions to develop talent and can shape the character and civilization of the nation to educate the nation's life. It aims to develop student's potential so that they become human beings in faith, pious to God Almighty, noble in character, knowledgeable, healthy, creative, capable, independent, and responsible and democratic as society" [4].

Science learning is a learning that has a significant role in improving the quality of education and producing a generation that can think critically because, in the learning of Biology, students are not only provided with a set of knowledge such as theory but then reinforced by experimental activities [5-6]. The discovery process can be initially passed with practicum activities. Practicum is an appropriate way to concretize material [7]. In practicum activities, it is necessary to have reference steps or work procedures so that the practicum can be implemented effectively [8-9].

Practical activities require a reference or instructions for implementing practice in the laboratory, which consists of work instructions, demonstrations, analyzing, and reporting the findings, referred to as practicum guides [10]. The practical manual guides students in conducting practicum [11]. The practicum guide is a guideline for teaching practicums that lecturers must own because the practicum guide aims to guide effective practicum learning methods [12].

A practicum guide is essential in conducting the learning process precisely during the practicum. Through the practicum guide, students have a reference about the process, objectives, and benefits of the practicum activities that are being conducted and clarifying the direction and targets of achievement in teaching practicum [13].

Students of the Biology Tadris Study Program at IAIN Palangka Raya must program a General Biology Practicum Course with a weight of 1 credit. This course was taken in semester 1 . One of the General Biology Practicum course objectives is that students can master the basics of science to support solving educational problems.

The learning process has been taking place so far. Students use a general Biology practicum guide in printed form, not yet equipped with Islamic integration and some complex work procedures to understand. Students have difficulty following work procedures in conducting practicum even though they have read the practicum guide. It causes the directory to be declared less feasible and practical and not in accordance with the Semester Learning Plan (RPS) made by the lecturer in the General Biology Practicum Course, which includes Islamic values.

Based on these problems, it is necessary to have a Practicum Guide that is designed and developed to make it easier for students to understand practical work procedures and to achieve one of the learning outcomes in accordance with the RPS made by the lecturer in General Biology Practicum Course, 
which is to have devotion to God Almighty and can show a religious attitude because learning that is integrated with religious values can provide the inculcation of values about divinity that are in line with the students' scientific concepts [14-15].

This research has a novelty value regarding the analysis of needs related to teaching materials in the form of a practicum guide which is expected to a later production of a practical guide that is interesting and practical to fits the needs of students in the General Biology practicum course.

\section{RESEARCH METHODS}

This research is a qualitative descriptive study with a survey method conducted in OctoberNovember 2021 at the Biology Tadris Study Program, IAIN Palangka Raya.

Only the analysis of the need for practical guide books was studied in this study. The population of this study was all 2018 Biology Tadris students, while the students who were used as samples were 22 Biology Tadris students at IAIN Palangka Raya taken by random sampling technique. Furthermore, a needs analysis questionnaire distributed online was used as part of the data collection technique. The data obtained were then analyzed using descriptive statistical methods.

\section{RESULTS AND DISCUSSIONS}

The results of observations made during the General Biology practicum lecture show that during the covid-19 pandemic, the practicum was conducted regarding health protocols; before entering the laboratory, students are required to wear masks and wash their hands first. Previously, students used a printed practicum guide with 14 topics during the practicum process. Still, during the pandemic period, only seven topics were practiced due to limited practicum time and limited tools and materials provided in the laboratory.

Based on the data obtained, it is known that the responses from students with a percentage of $54.5 \%$ stated that the General Biology practicum was a difficult subject to understand. The analysis results can be seen in the results of the questionnaire in Figure 1. General Biology Practicum is a difficult subject because it is a practicum that has many topics and becomes the basis for other future practicums.

The General Biology practicum has been equipped with a printed practicum guide. However, $68.2 \%$ of students stated that the practicum guide is less attractive. It is evidenced by the results of the needs analysis questionnaire in Figure 1. The unattractive practicum guide causes students to get bored in reading the manual. Thus, it makes it difficult for the students to understand the contents of the practicum guide.

The difficulty in understanding this general Biology practicum guide impacts practical activities.
It is evidenced by $81.8 \%$ of students having difficulty understanding work procedures, as evidenced by the student needs questionnaire analysis in Figure 1. The work procedure in the practicum guide is a very important point because it is a guide that students must pay attention to in doing a practicum. If students have difficulty understanding work procedures, it is feared that it will have an impact on practicum results that are not in accordance with the practicum objectives.

In the learning process at the religious university level, the inculcation of values about divinity can be done by applying learning integrated with religious values that are in line with the students' scientific concepts, hoping that students can grow their spiritual attitude. In fact, from the results of researchers' observations regarding the practicum guides used and from the questionnaire results of the needs analysis given to lecturers, it is known that the practicum guides used so far have not been integrated with Islamic values. Thus, $95.5 \%$ of students stated that developing an integrated Islamic practicum guide was necessary. The results of the analysis are presented in Figure 1.

Based on the needs analysis results, $72.2 \%$ of students stated the need to develop a General Biology practicum guide, and it is hoped that the developed practicum guide can be integrated with Islamic values in the form of an e-book allowing students to access the practicum guide via cellphone. The results of the analysis are presented in Figure 1.

Based on the needs analysis questionnaire given to the lecturer in charge of the General Biology Practicum course, it was found that the lecturer concerned agreed that the development of teaching materials in the form of a practicum guide is conducted. It is hoped that the developed practicum guide is in the form of an e-book and integrated with Islamic values so it can the need of the current situation, learning during a pandemic, either offline or online.

Based on the problems found in the analysis stage above, the researcher took the initiative to develop a product in a General Biology practicum guide using the Islamic-integrated Flip PDF Professional application. One software that can support the manufacture of electronic teaching materials is the Flip PDF Professional application [16]. Electronic teaching materials made with the Flip PDF Professional application focus not only on writing. Still, they can also include video, audio, and animation, which are fun interactive learning media, so the learning process is not dull and too monotonous [17].

Thus, the E-book created with the Flip PDF Professional application is expected to make the practical guide more attractive and can be accessed easily using a mobile phone in various formats such as App, Exe, Html, and Fbr [18-19]. The E-books can also be flipped back and forth like a 3D book, adding 
to the uniqueness of the practical guide [20].

In addition, learning that is integrated with religious values can instill spiritual importance in accordance with student scientific concepts [21-25]. Students are expected to have strong faith and purity

Do you agree if the product developed is in the form of an e-book?

Is it necessary to develop a practical guide that is integrated with Islamic values? Are there any difficulties in understanding the working
procedures of the General Biology practicum guide?

Is the practical guide used during the General Biology practicum interesting?

Is practicum in General Biology difficult to understand? because they can prove that the idea of science is also in line with the teachings of their religion. Thus, integrating Islamic values is necessary for the practical guide to help produce a generation that is intelligent in the cognitive and religious realms.

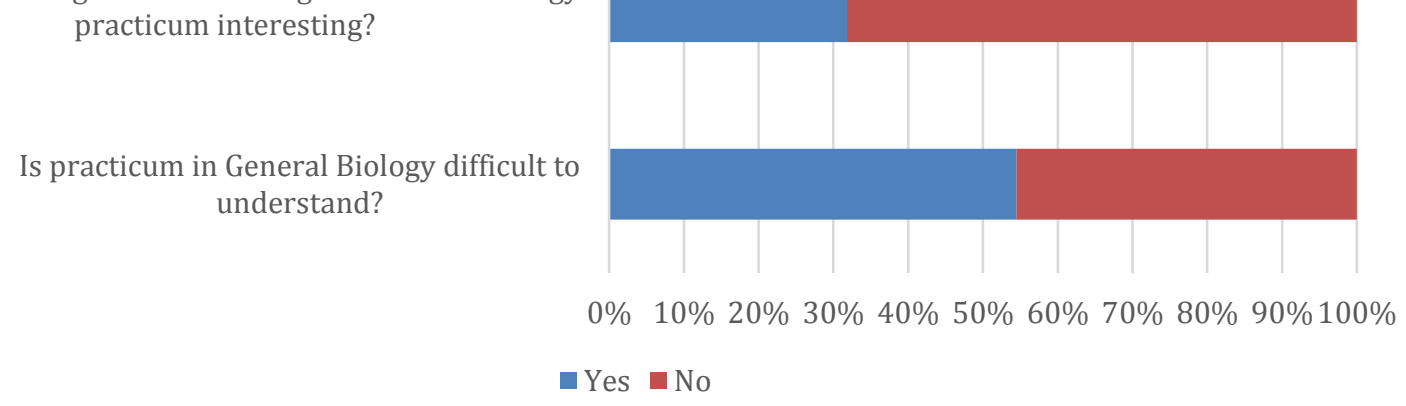

Figure 1. The results of the General Biology practicum lecture during pandemic Covid-19

Previous research on needs analysis has also been conducted by Asrizal 2017 with the research title "Analysis of the need to develop integrated science teaching materials containing digital era literacy for learning for seventh-grade junior high school students". This research shows that science teachers still have difficulties and are constrained in implementing integrated science learning, so it is necessary to develop teaching materials to facilitate teachers in the integrated science learning process [2630]. In line with this research which analyzes teaching materials in the form of a practicum guide, in the future, it is hoped that a practicum guide that suits the needs of students can be developed.

This research is only limited to the needs analysis stage. The authors hope that by referring to the results of this analysis, teaching materials in the form of practical guides will be developed according to the needs of students so that an attractive and practical practicum guide for students to use in this General Biology Practicum course will be achieved.

\section{CONCLUSION}

The data analysis made using observation techniques, interviews, and needs questionnaires shows that there is a need for an integrated Islamic General Biology practicum guide that is interesting and practical to use and can help students understand work procedures. Thus, based on the analysis results, products that can be developed are a General Biology practicum guide integrated with Islam using the Flip PDF Professional application.

\section{REFERENCES}

[1] Ashadi, F. (2016). Pengembangan Sumberdaya Manusia dalam Lembaga Pendidikan Anak Usia Dini. Jurnal Pembelajaran Fisika, 4(5), 717-729.

[2] Suwartini, S. (2017). Pendidikan karakter dan pembangunan sumber daya manusia keberlanjutan. Trihayu: Jurnal Pendidikan KeSD-an, 4(1).

[3] Sudarsana, I. K. (2016). Peningkatan Mutu Pendidikan luar sekolah dalam upaya pengembangan sumber daya manusia. Jurnal Penjamin Mutu, 1(1), 1-14. 
[4] Undang-Undang Republik Indonesia Nomor 20 Tahun 2003. Sistem Pendidikan Nasional. 2012. Bandung : Citra Utara.

[5] Pasaribu, V. I. (2021). Analisis Kemampuan Literasi, Berpikir Tingkat Tinggi, Keterampilan Proses Sains dan Sikap Mahasiswa pada PerkuliahanTaksonomiSpermatophyta (Doctoral dissertation, UNIMED).

[6] Setiawan, A. (2014). Pengembangan modul ipa terpadu berbasis sainsteknologi-masyarakat dengan tema pembuatan kompos sebagai sarana berpikir kreatif siswa SMP/MTs. UIN Sunan Kalijaga Yogyakarta. Retrieved from http://digilib.uin-suka.ac.id/13212/

[7] Nasution. 2010. Berbagai Pendekatan Dalam Proses Belajar Mengajar . Jakarta: Bumi Aksara.

[8] Alexander, A., Rahayu, H. M., \& Kurniawan, A. D. (2018). Pengembangan Penuntun Praktikum Fotosintesis Berbasis Audio Visual Menggunakan Program Camtacia Studio di SMAN 1 Hulu Gurung. Jurnal Pendidikan Sains Indonesia, 6(2), 75-82.

[9] Ariningsih, I., Nawawi, E., \& Hartono, H. (2014). Pengembangan Panduan Praktikum Kimia Berbasis Inkuiri Terstruktur Di Kelas Xii Sman 1 Indralaya Utara. Jurnal Penelitian Pendidikan Kimia: Kajian Hasil Penelitian Pendidikan Kimia, 1(2), 147-155.

[10] Al Idrus, S. W., Purwoko, A. A., Hadisaputra, S., \& Junaidi, E. (2020). Pengembangan Modul Praktikum Kimia Lingkungan Berbasis Green Chemistry Pada Mata Kuliah Kimia Lngkungan. Jurnal Pijar Mipa, 15(5), 541-547.

[11]Budiarti, W. \& Anak Agung, O. 2014. Pengembangan Petunjuk praktikum Biologi Berbasis Pendekatan Ilmiah untuk Siswa SMA Kelas XI Semester Genap Tahun Pelajaran 2013/2014. Jurnal Bioedukasi, 6(2):123-130.

[12] Prayitno, T. A. (2017). Pengembangan petunjuk praktikum mikrobiologi program studi pendidikan biologi. Jurnal Biota, 3(1), 31-37.

[13] Nurussarinah dan Nurhayati.2016. Pengembangan Penuntun Praktikum Fisika Dasar Berbasis Guided Inquiry Untuk Meningkatkan Kemampuan Berfikir Kritis Mahasiswa. Prosiding Seminar Nasional Fisika. 5: 63-68.

[14] Hanif, Ibrohim, \& Rohman, F. 2016. Pengembangan Perangkat Pembelajaran Biologi Materi Plantae Berbasis Inkuiri Terbimbing Terintegrasi Nilai Islam untuk Meningkatkan Pemahaman Konsep Siswa SMA. Jurnal Pendidikan: Teori, Penelitian, dan Pengembangan, 1(11), 2163-2171

[15] Asrizal, A., Festiyed, F., \& Sumarmin, R. (2017). Analisis kebutuhan pengembangan bahan ajar ipa terpadu bermuatan literasi era digital untuk pembelajaran siswa SMP kelas VIII. Jurnal Eksakta Pendidikan (JEP), 1(1), 1-
8.

[16] Watin, E., \& Kustijono, R. (2017). Efektivitas penggunaan e-book dengan flip PDF professional untuk melatihkan keterampilan proses sains. In Prosiding Seminar Nasional Fisika (SNF) (Vol. 1, pp. 124-129).

[17] Widiastutik, T. (2021). Pengembangan E-Modul Bahasa Indonesia Kelas Xii Dengan Flip Pdf Profesional Sebagai Alternatif Pembelajaraan Di Tengah Pandemi Covid 19. Inovasi-Jurnal Diklat Keagamaan, 15(1), 35-41.

[18] Nurhidayati, A., Putro, S. C., \& Widiyaningtyas, T. (2018). Penerapan Model Pbl Berbantuan E-Modul Berbasis Flipbook Dibandingkan Berbantuan Bahan Ajar Cetak Pengaruhnya Terhadap Hasil Belajar Pemrograman Siswa SMK. Teknologi dan Kejuruan: Jurnal Teknologi, Kejuruan, dan Pengajarannya, 41(2), 130-138.

[19] Seruni, R., Munawaroh, S., Kurniadewi, F., \& Nurjayadi, M. (2019). Pengembangan modul elektronik (e-module) biokimia pada materi metabolisme lipid menggunakan Flip PDF Professional. Jurnal Tadris Kimiya, 4(1), 48-56. untuk Meningkatkan Pemahaman Konsep Siswa SMA. Jurnal Pendidikan: Teori, Penelitian, dan Pengembangan, 1(11), 2163-2171.

[20] Maulana, I. (2020). Pengembangan E-Modul Flipbook Berbantuan Flip Pdf Professional Dengan Pendekatan Situation Based Learning (Sbl) Pada Pokok Bahasan Sistem Persamaan Linear Dua Variabel (Spldv) Kelas Viii Di Smp Negeri 12 Bandar Lampung (Doctoral dissertation, UIN Raden Intan Lampung).

[21] Ihsani, N., Al Idrus, A., \& Jamaludin, J. (2020). Perangkat Pembelajaran Biologi Berbasis Masalah Terintegrasi Nilai-Nilai Islami Untuk Meningkatkan Penguasaan Konsep Peserta Didik. Jurnal Pijar Mipa, 15(2), 103-109.

[22] Muchlis, M., Perkasa, M., Irwansyah, M., \& Ariyansyah, A. (2020). Pengembangan Modul IPA Berkarakter Terintegrasi Nilai-Nilai Islam untuk Meningkatkan Sikap Spiritual Peserta Didik SMP/MTs. Jurnal Pendidikan MIPA, 10(2), 81-85.

[23] Ilhamdi, M. L., Al Idrus, A., \& Santoso, D. (2021). Sikap Belajar Kaitannya dengan Hasil Belajar IPA Siswa Madrasah Tsanawiyah Al Maarif Praya Timur Kabupaten Lombok Tengah. Jurnal Pijar Mipa, 16(1), 129-135.

[24] Insani, G. N., Dewi, D., \& Furnamasari, Y. F. (2021). Integrasi Pendidikan Karakter dalam Pembelajaran Pendidikan Kewarganegaraan untuk Mengembangkan Karakter Siswa Sekolah Dasar. Jurnal Pendidikan Tambusai, 5(3), 81538160.

[25] Soleh, A. R., \& Arifin, Z. (2021). Integrasi Keterampilan Abad 21 dalam Pengembangan Perangkat Pembelajaran Pada Konsep 
Community of Inquiry. QALAMUNA: Jurnal Pendidikan, Sosial, dan Agama, 13(2), 473-490.

[26] Yaqin, M. A., Astuti, E. W., Anggraini, C. E. A., \& Hidayatullah, A. F. (2020). Integrasi AyatAyat Al-Qur'an dalam Pembelajaran Sains (Biologi) Berdasarkan Pemikiran Ian G. Barbour. Jurnal Kajian Pendidikan Sains, 6(1), 78-83.

[27]Edison, E., \& Fathurrochman, I. (2020). Pendidikan Sebagai Media Integrasi Agama Dan Sains Dalam Era Revolusi Industri 4.0. Jurnal Literasiologi, 3(1).

[28] Sulaiman, M. (2020). INTEGRASI AGAMA ISLAM DAN ILMU SAINS DALAM PEMBELAJARAN. Jurnal Studi Islam: Pancawahana, 15(1), 96-110.

[29] Afbrifani, V. (2020). Kajian Buku Ajar Siswa dalam Pembelajaran Sains dalam Bentuk Perspektif Integrasi Pembelajaran Sains dan Islam MI. MODELING: Jurnal Program Studi PGMI, 7(2), 258-269.

[30] Rahmatih, A. N., Maulyda, M. A., \& Syazali, M. (2020). Refleksi nilai kearifan lokal (local wisdom) dalam pembelajaran sains sekolah dasar: Literature review. Jurnal Pijar MIPA, 15(2), 151-156. 